\title{
Health education as an important tool in the healthcare system
}

\begin{abstract}
Health education is the main, and at the same time, integral part of complementary health promotion. The main assumption underlying the essence of health education is an assertion that the health of individuals and, consequently, of communities they belong to is significantly conditioned by the behaviour of inter-subject variability, which can be pro-healthily shaped by the educational impact. Thanks to transferred knowledge, shaping attitudes and the acquisition of certain skills, patients receive help in coping with health problems which improves their well-being, satisfaction, and the process of recovery. The education of a patient has advantages either in the clinical or social field, hence, it is perceived as an inseparable part of a high-quality healthcare. The importance of health education has been also recognized as one of the main factors that determine the long-term health policy, which indirectly may be reflected in the reduction of costs in the healthcare. In the recent years, more and more emphasis has been placed on preventive and educational aspects of the healthcare. Family medicine, as the source of the initiation of shaping health-oriented attitudes, has a prominent place in the system organized in such a way. In patients' opinion, medical staff is the best and most reliable source of knowledge on health. Such expectations increase the importance of primary care physicians in preventing diseases and shaping health-oriented attitudes in a given society. The main task of a modern health education is primarily to support the creation of conditions for change, the growth competence of individuals and groups in the sphere of independent action for health at different levels of the organization of social life.
\end{abstract}

Keywords: health education, health system, family medicine.

DOI: $10.2478 /$ pjph-2014-0032

\section{INTRODUCTION}

Health, which is defined as a full physical, psychic and social well-being not as a lack of an illness or an indisposition [1], constitutes a multi-sided value either individual or social. The health of a society influences the productive potential and prosperity of its citizens. Consequently, the healthcare has become one of the most essential sections of social policy of contemporary countries. Ongoing development in medicine constantly expands possibilities not only in the field of prevention and treatment of diseases but also the prolongation of life. Ageing of society has contributed to the increase of needs in this field. The health of a society depends not only on the standard of the healthcare, its availability and the quality of medical services but also on a good national policy whose aim is to implement healthcare programmes [2-4].

Since the principles concerning health promotion of the Ottawa Charter were formulated in 1986, it has become one of the four main directions in the European Strategy of Health [1]. The stimulus for the development of contemporary methods for health promotion was an increase of modern age diseases in the 70 s of 20 th century, diseases, which were strongly determined by a lifestyle, so-called behavioral diseases. The human being started to be perceived as a creator of one's own health and the meaning of their choices concerning health became very important [5]. Health promotion endeavors to develop such actions of a society and individuals, which may help people to achieve such a lifestyle which would help them maintain and boost their well-being. The evolution of the modern healthcare in the direction of a widely understood health promotion and the prevention of disease has become inevitable and the role of the medical environment in the prevention of diseases is irrefutable [6]. The recognition of a demographic situation and health problems in the population has become the basis for various preventive, diagnostic and therapeutic, rehabilitation and educational actions [7].

Health education is the main, inherent and complementary at the same time element of health promotion $[8,9]$. Its aim is to raise awareness, expand knowledge, gain skills and shape a health-oriented attitude of particular

\footnotetext{
${ }^{1}$ The Chair and Department of Hygiene, Medical University in Lublin, Poland

${ }^{2}$ The Chair and Department of Public Health, Medical University in Lublin, Poland

${ }^{3}$ First Department of Radiology, Medical University in Lublin, Poland

${ }^{4}$ Faculty of Social Sciences, The John Paul II Catholic University of Lublin, Poland
} 
individuals who are also perceived as elements of a society $[3,8]$. Health education is a process in which people learn how to take care of their health and the health of their community. The process concentrates on making people realize the relation between one's health, their lifestyle, physical and social setting. It does not solely mean transferring the knowledge, but it allows the learner to apply the knowledge effectively i.e. consider, think, make decisions and take actions concerning health, gain skills which help to improve it. As a result of health education, awareness increases, an ability to make decisions concerning health enhances, knowledge and skills connected not only with health and sickness but also the prevention and coping with difficult situations improve. The scope of knowledge and skills regarding the proper use of the healthcare expands, both the level of social, political awareness and the awareness of environmental factors affecting health increases $[3,7,8]$. The main assumption underlying the essence of health education is the statement that health of individuals and, consequently, communities they belong to is significantly conditioned by behavior of an individual which may be pro-healthily shaped thanks to the impact of education [8]. The basic task of modern health education is, first and foremost, to create the conditions for change, the growth of the competence of individuals and groups in the field of individual actions for health at different levels of a social life $[3,8,9]$. It has become a universal tool, which may be used at every stage of prevention enabling the solutions of problems connected with the specificity of its particular levels. Educational programmes directed to every age group and groups of patients with diagnosed diseases e.g. diabetes, evidence it $[8,10]$.

Health-oriented education is not a novelty. It has been implemented in Poland since 1982 when various prophylactic programmes, based on the guidelines prepared by excellent specialists, were introduced to schools [8]. Taking into consideration experience and strategies for health protection, health education programmes are intensively administered in a school environment e.g. Health-Friendly School (Szkoła Przyjazna Zdrowiu) with the aim to shape health-oriented attitudes, which will result in a decreased incidence of diseases in society in the future $[8,11]$.

At present, health education is practically included in all health and strategic programmes carried out at various levels of social life i.e. in a family, school, work, towns and cities, regions, global societies and international communities. The examples include: White Paper - Together for Health (a national health programme for 2007-2015), National Health Programme against Diseases of Affluence, National Health Program for Fighting Cancer, the Strategy of Development of Healthcare in Poland, Strategy of Changes in Healthcare or an idea of a many-sided health education in schools recommended by UNESCO $[12,13]$.

In the recent years in the face of helplessness to rapidly increasing civilization health problems in highly developed countries, a greater emphasis is placed on a preventive and educational aspect of the healthcare $[5,8]$. A created model of education for change takes into account a multiple causality of diseases taking into consideration not only behavioral but also social, economic and political determinants of health and the necessity to implement educational health programmes at three levels: an individual, community and whole society $[3,8,14]$. Family medicine holds the most important place in such a system as a point of initiation of shaping health-oriented behavior. Medical staff is considered the best and the most reliable source of knowledge on health. Such expectations increase the importance of primary care physicians in preventing diseases and shaping health-oriented attitudes in a given society [6]. The role of a family physician, in the face of healthcare contracts, apart from treating means also preventing and educating. Adding these tasks to the competence of family medicine gains more importance and demonstrates a strong tendency to become a priority especially in the context of a long-term health policy $[15,16]$. However, the existing obstacles in the form of a faulty organization of the healthcare, the lack of cooperation with a patient and their environment or insufficient time which family physicians can devote to a patient make it difficult to fulfill the educational role [15-18].

At the existing level of health in society connected with a demographic situation, health education and broadly defined preventive actions are becoming more and more significant as one of change factors in the management strategies of the healthcare. Education of a patient has both clinical and social advantages [15]. Thanks to the transferred knowledge, shaping attitudes and acquisition of certain skills, patients receive help in dealing with health problems which influences their mood, satisfaction and the process of recovery $[15,16]$. Due to this fact, health education is perceived as an inseparable part of a high-quality healthcare [15]. It has been demonstrated that health education together with other actions typical of health promotion can contribute to the decrease of costs in the healthcare. It has a crucial meaning for the management of the healthcare especially in the face of chronic lack of financing in medical services and rising costs of care and treatment connected with the growth of the incidence of chronic diseases $[5,15]$. Therefore, education of a patient constitutes one of the most important challenges for the healthcare, especially in the context of enhancing its effectiveness [7,15]. Primary care physicians play and will play the leading role in the aforementioned situation since patients expect to gain knowledge on health and shaping health-oriented attitudes from them [15]. A constantly growing impact on health education and promotion in modern healthcare systems makes the quote 'better the prevention than cure' become the determinant for medicine in the future.

The most crucial conclusion in the face of the aforementioned facts is that the role of a primary care physician as a person responsible for health education of society will constitute one of the cornerstones of medicine. 


\section{REFERENCES}

1. Bzdęga J, Gębska-Kuczerowska A. Epidemiologia w zdrowiu publicznym. Warszawa: Wydawnictwo Lekarskie PZWL; 2010.

2. Skawińska M. Analiza funkcjonowania systemów opieki zdrowotnej w wybranych krajach Unii Europejskiej (na przykładzie Szwecji, Wielkiej Brytanii, Polski i Niemiec). Studia ed.. 2009;13:69-77.

3. Książek P, Herda J, Pawka B, et al. Health education as an Essential standard in healthcare prevention for students in education environment in Lublin. Zdr Publ. 2008;118(4):403-5.

4. Buzowska B. "Urynkowiony" system usług medycznych - argument za i przeciw. Zdr Publ. 2008;118(2):202-5.

5. Miller M, Wysocki M. Promocja zdrowia $z$ kontekście reformy systemu ochrony zdrowia w Polsce. Zdr Publ. 2005;115(1):78-81.

6. Misiuna M. Zmiany ocen opieki zdrowotnej i ich społeczne zróżnicowanie. Zdr Publ 2005; 115(3): 296-302.

7. Piecewicz-Szczęsna H, Karwat D. Problemy zdrowotne i demograficzne społeczeństwa polskiego a rodzaje zadań w zakresie edukacji zdrowotnej. Zdr Publ. 2010;120(3):295-9.

8. Woynarowska B. Edukacja zdrowotna. Podręcznik akademicki. Warszawa: Wydawnictwo Naukowe PWN; 2007.

9. Furtak M, Książek P, Warchoł-Sławińska E, et al. Develpoment of health care market - forecasts for the future. Zdr Publ. 2011;121(1):76-80.
10. Rusinowicz T, Gromek M, Olędzka-Olęziak M, et al. Wpływ standardowej edukacji na zmianę masy ciała u pacjentów z cukrzycą typu 2 leczonych w Poradni Chorób Metabolicznych. Fam Med. Prim Care Rev. 2009;11(3):476-8.

11. Woynarowska B. Ścieżka edykacyjna-edukacja prozdrowotna i promocja zdrowia w szkole. Warszawa: Krajowy Ośrodek Wspierania Edukacyji Zawodowej; 2001.

12. Biała Księga Komisji Wspólnot Europejskich - Razem na Rzecz Zdrowia: Strategiczne podejście dla UE na lata 2008-2013. Bruksela, 23.10.2007 KOM(2007) 630 wersja ostateczna. [www.ec.europa.eu].

13. [www.mz.gov.pl]

14. Boratyn-Dubiel L, Chmiel Z. Znaczenie edukacji zdrowotnej dla pacjentów z cukrzycą. Zdr Publ. 2010;120(3):316-23.

15. Cianciara D, Miller M. Postawy lekarzy wobec edukacji pacjenta. Przegl Epidemiol. 2003;57:531-40.

16. Celczyńska-Bajew L. Opinia lekarzy rodzinnych dotycząca warunków pozwalających utrzymać pacjenta w terapii chorób przewlekłych. Fam Med. Prim Care Rev. 2009;11(3):255-7.

17. Mardarowicz G, Mardarowicz K, Matej-Butrym A, et al. Badania profilaktyczne pacjentów Lubelszczyzny. Jakie czynniki warunkują gotowość do współpracy ze służbą zdrowia? Fam Med. Prim Care Rev. 2009;11(3):398-400.

18. Mastalerz-Migas A, Szymczyk K, Muszyńska A, et al. Poglądy rodziców na temat aktywności fizycznej i nadwagi u własnych dzieci wyobrażenia i rzeczywistość. Fam Med. Prim Care Rev. 2009;11(3):4113 .

\section{Corresponding author}

The Chair and Department of Hygiene, Medical University in Lublin 11 Radziwillowska Str. (Collegium Medicum), 20-080 Lublin

tel.: +48 81 528-84-02

E-mail: katedra.higieny@umlub.pl 